\title{
Fenomena Harmful Algal Blooms (HABs) di Pantai Ringgung Teluk Lampung, Pengaruhnya dengan Tingkat Kematian Ikan yang Dibudidayakan pada Karamba Jaring Apung
}

\section{Phenomenon of Harmful Algal Blooms (HABs) in Ringgung Beach- Lampung Bay, Inluence for Fish Mortality on Cage Culture}

\author{
Ade Irawan $^{1}$, Qadar Hasani ${ }^{2}$, dan Herman Yuliyanto ${ }^{2}$ \\ ${ }^{1}$ Mahasiswa Juruswan Budidaya Perairan, Fak. Pertanian \\ ${ }^{2}$ Dosen Juruswan Budidaya Perairan, Fak. Pertanian Universitas Lampung \\ Jln. Soemantri Brojonegoro No 1 Gedung Meneng Bandar Lampung
}

\begin{abstract}
Fish mortality in the Bay of Lampung not only wild fish, but also fish farmed in cages, especially Ringgung Beach. One which caused by harmful algal abundance that occur was increased input contaminants by both natural and anthropogenic sources. This study aims to analyze the influence of harmful algal blooms (HABs) the amount and frequency of fish mortality in cage Ringgung Lampung Bay. The study was conducted at three research stations based KJA density. The results of the study found 33 species of phytoplankton, 14 species have potential as HABs can cause the death of fish. The highest abundance was kind Cochlodinium that reach 63.738 cells/liter. Phytoplankton diversity index value with the lowest value occurred at station 3 on June 19, 2013 ie the date of 0705. The highest phytoplankton diversity values occurred at Station 2 on June 12, 2013 is 2,451. Uniformity values of phytoplankton in the waters of Beach Ringgung obtained in the high category with a value above 0.5 or close to 1, which indicates that the spread of the individual any kind of relatively evenly. Except at station 3 which has a relatively low value (0.228 on June 19, 2013, 0291 on June 26, 2013, and 0446 on July 3, 2013). Effect of HABs on the fishing mortality rate is indicated by regression analysis. Correlation coefficient at station 1 shows the value of 0.5208. While on station 2 shows 0.6937. Harmful algal blooms shown to affect mortality rates of fish in floating net Ringgung Beach. They have triggered reduced oxygen levels in the water that could potentially cause the death of wild fish and farmed in floating net
\end{abstract}

Keywords: Dead fish, harmful phytoplankton, floating net 


\section{PENDAHULUAN}

Ledakan fitoplankton dapat dipicu oleh meningkatnya unsur hara dalam perairan. Mengingat bahan-bahan tersebut sangat penting bagi perkembangan dan pertumbuhan fitoplankton, maka hubungan antara kesuburan perairan dengan kondisi komunitas fitoplankton sangat erat (Qiptiyah et al. 2008). Praseno et al. (2000) menyatakan bahwa fitoplankton umumnya berdampak positif bagi kehidupan di laut. Namun demikian ledakan populasi dari beberapa jenis fitoplankton dapat berdampak negatif. Karena jika fitoplankton berbahaya ada di dalam budidaya maka akan mengganggu keberlangsungan ikan budidaya. Salah satu pantai di Teluk Lampung yang digunakan untuk budidaya ikan adalah Pantai Ringgung. Fenomena Harmful Algal Blooms (HABs) di Perairan Teluk Lampung pernah terjadi sekitar pukul 09.00 (17-10) di sejumlah titik (Muawanah, 2012). Kondisi perairan diawali dengan perubahan warna air laut menjadi cokelat kemerahan diikuti dengan kematian ikan secara massal. Informasi tentang kematian ikan yang disebabkan fitoplankton berbahaya belum banyak dibahas. Oleh karena itu perlu dilakukannya penelitian untuk mengetahui pengaruh kemunculan fitoplankton berbahaya (HABs) terhadap tingkat kematian ikan dalam budidaya ikan di sekitar Pantai Ringgung. (Hasani et al. 2012) menyatakan bahwa peningkatan kadar nitrat mengakibatkan peningkatan kelimpahan total fitoplankton. Mulyasari et al. (2003) menyatakan terjadinya blooming fitoplankton mikroskopis yang hidup di lingkungan perairan dapat menimbulkan dampak negatif. Blooming fitoplankton dapat menyebabkan kematian ikan akibat kekurangan oksigen dan pembusukan.

Penelitian ini bertujuan menganalisis pengaruh kelimpahan fitoplankton berbahaya (HABs) terhadap jumlah dan frekuensi kematian ikan dalam Karamba Jaring Apung di Pantai Ringgung Teluk Lampung. Hasil penelitian ini diharapkan dapat memberikan informasi tentang fitoplankton berbahaya yang menyebabkan kematian ikan. Dengan begitu dapat menjadi acuan sebagai upaya dalam optimalisasi hasil panen ikan budidaya.

\section{METODE}

Bahan yang digunakan dalam pengambilan data dan penelitian diantaranya formalin $4 \%$, sampel air dan fitoplankton. Sedangkan alat-alat yang digunakan dalam pengambilan data dan penelitian ini yaitu botol plastik/gelas $100 \mathrm{ml}$, jala plankton, kertas label, termometer, refraktometer, cakram secchi, buku identifikasi, Sadgwick Raffter, gelas penutup, mikroskop, alat pengukur arus buatan. Dalam pengambilan data sampel plankton dilakukan secara aktif dengan menggunakan plankton net nomor 20. Agar penarikan sampel plankton dapat mewakili fitoplankton pada berbagai kedalaman, penarikan jala plankton dilakukan secara vertikal dari dasar menuju permukaan perairan (Dewi, 2012). Sampel dibawa ke laboratorium untuk diidentifikasi. Pengambilan sampel pada masing-masing titik dilakukan berurutan secara tetap setiap minggu. Sampel fitoplankton diidentifikasi menggunakan buku identifikasi dari (Wickstead, 1965) dan (Yamaji, 1966). Penentuan kelimpahan plankton dihitung dengan menggunakan rumus (Dianthani, 2003) sebagai berikut:

$$
N=n\left(\frac{V r}{V o}\right) x\left(\frac{1}{V s}\right)
$$

Dimana : $\quad \mathrm{N}=$ Jumlah sel per liter (ind/l)

$\mathrm{Vr}=$ Volume air tersaring $(\mathrm{ml})$

$\mathrm{n}=$ Jumlah sel yang diamati atau didapat

$\mathrm{Vs}=$ Volume air yang disaring (l)

Vo = Volume air yang diamati $(\mathrm{ml})$ 
Penentuan fitoplankton yang termasuk HABs dengan mengacu pada (Sidharta, 2005), (Romimohtarto et al. 2001), (Brusle', 1995) dan (Kim, 2002). Sedangkan untuk mengetahui pengaruh kemunculan fitoplankton berbahaya di KJA terhadap jumlah kematian ikan maka dilakukan uji regresi dengan mengacu pada (Walpole, 1991).

\section{HASIL DAN PEMBAHASAN}

Fitoplankton yang teridentifikasi dari hasil penelitian terdapat 33 jenis. 19 jenis dari kelompok bacillariophyceae, 11 jenis dari kelompok dinophyceae, 2 jenis dari kelompok protozoa, dan 1 jenis dari kelompok Cyanophyceae.

Tabel 1. Kelimpahan fitoplankton pada masing-masing stasiun berdasarkan waktu penelitian

\begin{tabular}{ccccccc}
\hline \multirow{2}{*}{ Stasiun/Tgl. } & \multicolumn{7}{c}{$\mathrm{N}$ (sel/liter) } \\
\cline { 2 - 7 } & 29 Mei '13 & 5 Juni ‘13 & 12 Juni '13 & 19 Juni ‘13 & 26 Juni ‘13 & 3 Juli ‘13 \\
\hline 1 & 11.930 & 40.561 & 23.405 & 16.758 & 17.667 & 11.475 \\
2 & 10.623 & 29.029 & 21.701 & 23.064 & 16.247 & 8.862 \\
3 & 17.554 & 15.338 & 17099 & 74.532 & 71.578 & 19.201 \\
\hline
\end{tabular}

Dari hasil penelitian, terdapat 14 jenis fitoplankton yang potensial sebagai HABs yaitu, Cerataulina bergonii, Nitzschia lanceolata, Pirodinium bahamense, dan Pseudo-nitzchia dari kelompok bacillariophyceae; Ceratium furca, Ceratium tripos, Dinophysis homunculus, Gonyaulax apiculata, Gymnodinium, Noctiluca scintilans, Prorocentrum lima, Protoperidinium, dan Cochlodinium dari kelompok dinophyceae; serta Trichodesmium erythraeum dari kelompok Cyanophyceae. Dengan tingkat ledakan populasi yang berbeda-beda. Dari 14 jenis tersebut, ledakan tertinggi adalah jenis Cochlodinium yang mencapai 63.738 sel per liter. Ledakan populasi tersebut terjadi pada 19 Juni 2013 di stasiun 3 yang diduga menyebabkan kematian ikan mencapai 20 ekor di karamba tersebut. Pada tanggal tersebut, DO terendah yaitu 4,42. Dibandingkan 2 stasiun lainnya yang diatas 5 yaitu 5,31 di stasiun 1 dan 5,24 di stasiun 2 .

Tabel 2. Tingkat Kematian Ikan pada masing-masing stasiun berdasarkan waktu penelitian

\begin{tabular}{cccccccc}
\hline \multirow{2}{*}{ Stasiun/Tgl. } & \multicolumn{5}{c}{ kematian ikan (ekor) } \\
\cline { 2 - 7 } & 29 Mei 2013 & 5 Juni 2013 & 12 Juni 2013 & 19 Juni 2013 & 26 Juni 2013 & 3 Juli 2013 \\
\hline 1 & 4 & 0 & 2 & 1 & 1 & 2 \\
3 & 2 & 0 & 6 & 20 & 12 & 11 \\
\hline
\end{tabular}

Tingginya populasi fitoplankton beracun di dalam suatu perairan dapat menyebabkan berbagai akibat negatif bagi ekosistem perairan, seperti berkurangnya oksigen di dalam air yang dapat menyebabkan kematian berbagai makhluk air lainnya (Damar, 2006). Fitoplankton berbahaya bahkan dapat menjadi faktor terjadinya kematian massal ikan. Karena dapat menyebabkan berkurangnya kandungan oksigen di perairan. Kematian menjadi lebih cepat jika plankton itu menempel di sirip ikan atau insang. Salah satu fitoplankton tersebut adalah Trichodesmium spp. Dari hasil penelitian, tercatat pada tanggal 19 Juni 2013 tingkat kematian ikan paling tinggi di stasiun 3 yaitu 19 ekor. Nampak dari pengukuran kualitas air DO stasiun 3 hanya 4,42. Nilai ini paling rendah dibandingkan dengan dua stasiun lainnya. Gas $\mathrm{O}_{2}$ tergolong reaktif serta kelarutannya dipengaruhi oleh temperatur 
dan salinitas. Semakin tinggi temperatur dan salinitas perairan maka semakin kecil kelarutan $\mathrm{O}_{2}$ dalam air (Kurniawan, 2008). Temperatur dan salinitas selama penelitian tidak berbeda jauh yakni kisaran 29-32. Hal ini dimungkinkan terjadinya penurunan DO bukan karena tingginya temperatur dan salinitas, melainkan ledakan fitoplankton.

Oksigen terlarut di perairan dihasilkan melalui proses fotosintesis oleh fitoplankton. Akan tetapi tingkat respirasi akan lebih besar daripada fotosintesis ketika tidak ada cahaya matahari. Hal ini tidak hanya terjadi di malam hari. Ketika fitoplankton bloom, maka cahaya matahari pun terhalang untuk masuk ke dalam kolom air. Sehingga oksigen terlarut semakin berkurang. Salmin (2005) menyatakan bahwa pada lapisan permukaan, kadar oksigen akan lebih tinggi, karena adanya proses difusi antara air dengan udara bebas serta adanya proses fotosintesis.

Dengan bertambahnya kedalaman akan terjadi penurunan kadar oksigen terlarut, karena proses fotosintesis semakin berkurang dan kadar oksigen yang ada banyak digunakan untuk pernapasan dan oksidasi bahan-bahan organik dan anorganik. Konsentrasi $\mathrm{O}_{2}$ terlarut adalah parameter penting dalam menentukan kualitas perairan. Konsentrasi $\mathrm{O}_{2}$ dipengaruhi oleh keseimbangan antara produksi dan konsumsi $\mathrm{O}_{2}$ dalam ekosistem. $\mathrm{O}_{2}$ diproduksi oleh komunitas autotrof melalui proses fotosintesis dan dikonsumsi oleh semua organisme melalui pernapasan. Kelarutan $\mathrm{O}_{2}$ di dalam laut dipengaruhi oleh suhu dan salinitas. Semakin tinggi suhu dan salinitas perairan maka kelarutan $\mathrm{O}_{2}$ semakin kecil. Pada umumnya lapisan permukaan laut mengandung $\mathrm{O}_{2}$ terlarut sebesar 4,5 - $9 \mathrm{mg} / \mathrm{l}$ (Sanusi, 2006).
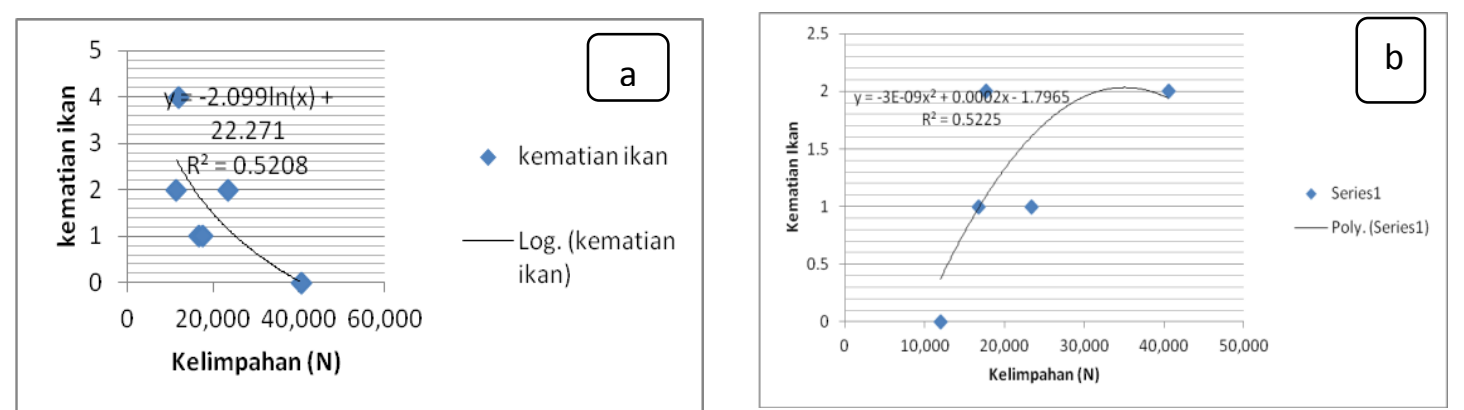

Gambar 3. Hasil Regresi Stasiun 1 yang menggambarkan pengaruh kelimpahan HABs terhadap tingkat kematian ikan di KJA Pantai Ringgung. (a) pengaruh kelimpahan fitoplankton terhadap kematian ikan pada pekan yang sama, (b) pengaruh kelimpahan fitoplankton terhadap kematian ikan pada pekan selanjutnya.

Berdasarkan gambar 3 (a) dilihat nilai $\mathrm{R}=0,5208$ artinya pengaruh kepadatan fitoplankton berbahaya terhadap kematian ikan adalah sebesar 52,08\%. Koefisien korelasi menunjukkan angka negatif atau berlawanan arah yaitu dengan adanya kenaikan kelimpahan fitoplankton berbahaya maka akan diikuti dengan penurunan tingkat kematian ikan. Selain itu nilai korelasi mendekati angka 1, hal ini berarti kelimpahan fitoplankton dan tingkat kematian ikan mempunyai hubungan yang kuat. Sedangkan nilai koefisien determinasi sebesar 0,7216 artinya pengaruh kelimpahan fitoplankton terhadap kematian ikan adalah sebesar 71,16\% dan sisanya dipengaruhi oleh variabel lain.

Sedangkan pada gambar 3 (b) dilihat nilai $\mathrm{R}=0,5225$ artinya pengaruh kepadatan fitoplankton berbahaya terhadap kematian ikan adalah sebesar 52,25\%. Koefisien korelasi menunjukkan angka positif atau searah yaitu dengan adanya kenaikan kelimpahan fitoplankton berbahaya maka akan diikuti dengan kenaikan tingkat kematian ikan. Namun karena hubungan polynomial, maka pada kelimpahan tertentu makin melimpahnya fitoplankton akan diikuti dengan menurunnya tingkat kematian ikan. 
Pada stasiun 3 nilai $\mathrm{R}$ lebih besar dari stasiun 1 yaitu sebesar 0,6937 artinya pengaruh kepadatan fitoplankton berbahaya terhadap kematian ikan adalah sebesar 69,37\%. Sedangkan nilai koefisien determinasi sebesar 0,8328 artinya pengaruh kelimpahan fitoplankton terhadap kematian ikan adalah sebesar $83,28 \%$ dan sisanya dipengaruhi oleh variable lain. Kondisi perairan stasiun 3 yang dekat pantai lebih berpotensi terhadap meningkatnya kelimpahan fitoplankton berbahaya yang dapat berdampak bagi kematian ikan yang dibudidayakan di karamba. Hal ini diduga akibat turbulensi kolom air pada stasiun 3 yang kondisinya lebih tenang daripada stasiun 1 dan 2 .

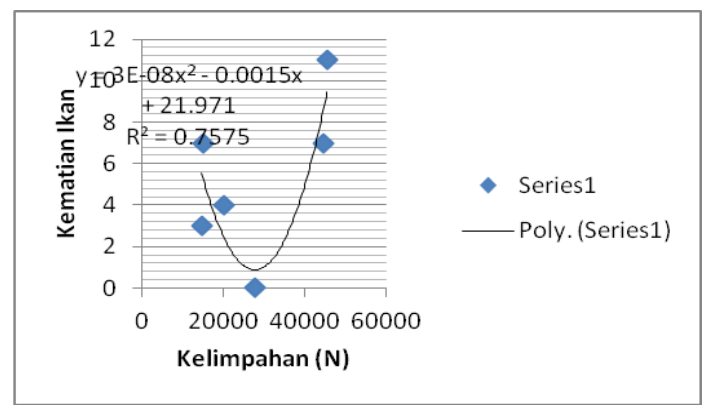

Gambar 4. Hasil Regresi rata-rata Stasiun 1 dan 3 yang menggambarkan pengaruh kelimpahan HABs terhadap tingkat kematian ikan di KJA Pantai Ringgung.

Hasil Regresi rata-rata Stasiun 1 dan 3 yang menggambarkan pengaruh kelimpahan HABs terhadap tingkat kematian ikan di KJA Pantai Ringgung disajikan dalam gambar 4. Dari nilai rata-rata kedua stasiun yang terdapat KJA nya (stasiun 1 dan stasiun 3), didapatkan nilai $\mathrm{R}=0,7575$ artinya pengaruh kepadatan fitoplankton berbahaya terhadap kematian ikan adalah sebesar 75,75\%. Semakin Nilai korelasi mendekati angka 1, hal ini berarti kelimpahan fitoplankton dan tingkat kematian ikan mempunyai hubungan yang kuat. Dengan adanya kenaikan kelimpahan fitoplankton berbahaya maka akan diikuti dengan kenaikan tingkat kematian ikan. akan tetapi hasil hubungan polynomial menunjukkan pada kelimpahan tertentu makin melimpahnya fitoplankton akan diikuti dengan menurunnya tingkat kematian ikan. titik baliknya berada pada koordinat $\mathrm{X}=27.000$ dan $\mathrm{Y}=1$. Sedangkan nilai koefisien determinasi sebesar 0,8703 artinya pengaruh kelimpahan fitoplankton terhadap kematian ikan adalah sebesar $87,03 \%$ dan sisanya dipengaruhi oleh variabel lain.

\section{KESIMPULAN}

Peningkatan kelimpahan fitoplankton berbahaya maka akan diikuti dengan kenaikan tingkat kematian ikan. Namun pada kondisi lain, kelimpahan tertentu makin melimpahnya fitoplankton akan diikuti dengan menurunnya tingkat kematian ikan.

\section{DAFTAR PUSTAKA}

Brusle' J. 1995. The Impact of Harmful Algal Blooms on Finfish. Mortality, Pathology and Toxicology. Prepignan cedex. France. 65pp

Damar, A. 2006. Musim Hujan dan Eutrofikasi Perairan Pesisir. Majalah Tempo. 30 November 2006. 
Ade Irawan ddk: Pengaruh Fitoplankton Berbahaya (HABs) Terhadap Tingkat Kematian Ikan

Dewi, D. Rengganis. 2012. Fitoplankton Penyebab Harmful Algae Blooms (HABs) di Perairan Teluk Jakarta. ITS. Surabaya.

Dianthani, D. 2003. Identifikasi Jenis Plankton di Perairan Muara Badak, Kalimantan Timur. Institut Pertanian Bogor.

Hasani, Qadar., Enan MA, Niken Tunjung MP. 2012. The Relationship between the Harmful Algal Blooms (HABs) Phenomenon with Nutrients at Shrimp Farms and Fish Cage Culture Sites in Pesawaran District Lampung Bay. Jurnal Makara Sains Vol. 16 No. 3 Desember 2012: 183191

Kim D, Oda T, Muramatsu T, Matsuyama Y, Honjo T. 2002. Possible factors responsible for toxicityof Cochlodinium polykrikoides, a red tide phytoplankton. Comp Biochem Physiol C Toxicol Pharmacol. Aug:132(4):415-23

Kurniawan, Galih.2008. Studi Ekologi Kista Dinoflagellata Spesies Penyebab HAB (harmful algal bloom) di Sedimen pada Perairan Teluk Jakarta. IPB: Bogor. Skripsi. Hal 23

Muawanah. 2012. Pasang Merah Muncul di Teluk Lampung. Koran Lampung Post. 25 Oktober 2012.

Mulyasari, Rosmawaty Peranginangin, Th. Dwi Suryaningrum, dan Abdul Sari. 2003. Penelitian Mengenai Keberadaan Biotoksin pada Biota dan Lingkungan Perairan Teluk Jakarta. Jurnal Penelitian Perikanan Indonesia Vol. 9 No. 5 Tahun 2003: 39-64

Praseno, Djoko Prawoto \& Sugestiningsih. 2000. Retaid di Perairan Indonesia. Pusat Penelitian dan Pengembangan Oseanografi-LIPI. Jakarta. $82 \mathrm{hlm}$.

Qiptiyah, Halidah dan Rahman MA. 2008. Struktur Komunitaas Plankton Di perairan Mangrove Dan Perairan Terbuka Di Kabupaten Sinjay, Sulawesi Selatan. Jurnal Penelitian Hutan dan Konservasi Alam, 5(2):137-143.

Romimohtarto, K., dan Sri Juwana. 2001. Biologi Laut. Ilmu Pengetahuan tentang Biota Laut. Penerbit Djambatan. Jakarta.

Salmin. 2005. Oksigen Terlarut (DO) dan Kebutuhan Oksigen Biologi (BOD) sebagai Salah Satu Indikator untuk Menentukan Kualitas Perairan. Jurnal Oseana, Volume XXX, Nomor 3, 2005 : $21-26$.

Sanusi, H. S. 2006. Kimia Laut (Proses Fisik Kimia dan Interaksinya Dengan Lingkungan) .FPIKIPB. Bogor.

Sidharta, B. R. 2005. The current status of research on harmfull algal bloom (HAB) in Indonesia. Jurnal of Coastal Development. 6(2):73-85

Walpole, R. E. 1991. Pengantar Statistika. Edisi Ke-3. Gramedia Pustaka Utama. Jakarta.

Wickstead, J. H. 1965. An Introduction To The Study of Trophical Plankton. London: Hutchinson \& Co (Publishers)

Yamaji, I. 1966. Illustration of the Marine Plankton of Japan. Osaka, Japan: Hoikusho 